\title{
Identification of peptides in traditional and probiotic sheep milk yoghurt with angiotensin I-converting enzyme (ACE)-inhibitory activity
}

\author{
Christos G. Papadimitriou ${ }^{a}$, Anna Vafopoulou-Mastrojiannaki ${ }^{a, *}$, Sofia Vieira Silva ${ }^{b}$, \\ Ana-Maria Gomes ${ }^{b}$, Francisco Xavier Malcata ${ }^{b}$, Efstathios Alichanidis ${ }^{a}$ \\ a Department of Food Science and Technology, Aristotle University of Thessaloniki, GR-54124 Thessaloniki, Greece \\ ${ }^{\mathrm{b}}$ Escola Superior de Biotecnologia, Universidade Católica Portuguesa, Rua Dr. António Bernardino de Almeida, \\ P-4200-072 Porto, Portugal
}

Keywords: Yoghurt; Sheep milk; Peptides; Proteolysis; ACE-inhibitory activity

\begin{abstract}
Two sets of traditional Greek sheep milk yoghurt were produced: the first one (YC) using normal yoghurt culture (Lactobacillus delbrueckii subsp. bulgaricus $\Upsilon 10.13$ and Streptococcus thermophilus $\Upsilon 10.7$ ) and the second (PR) with the same normal culture mixed with Lactobacillus paracasei subsp. paracasei DC412. YC and PR had similar physicochemical properties and proteolysis patterns throughout storage. Both products showed similar peptide profiles by RP-HPLC but quantitative differences were observed in respect to storage time. Single-strain cultures of the microorganisms used showed similar peptide profiles for both lactobacilli, yet L. delbrueckii subsp. bulgaricus was the most proteolytic of all three microorganisms. The peptide content and the ACE-inhibitory activity of the water-soluble extracts of yoghurts, YC and PR, increased throughout storage. Major peptides were identified from yoghurt PR and from the separate cultures of $L$. delbrueckii subsp. bulgaricus and L. paracasei subsp. paracasei. Most of these peptides were derived from $\beta$-casein. A peptide, $\beta$-CN f114-121, with well-established ACE-inhibitory and opiate-like activity was identified in yoghurt PR. Further identified peptides were regarded as potential ACE-inhibitors according to their sequence.
\end{abstract}

\footnotetext{
Abbreviations: ACE, angiotensin-I converting enzyme; \%IACE, percentage of inhibition of ACE; IC50, the concentration needed to inhibit $50 \%$ of the enzyme activity; RP-HPLC, reversed-phase high performance liquid chromatography; TCA, trichroloacetic acid; DH, degree of hydrolysis; WSE, water soluble extract; OPA, $o$-phthaldialdehyde; TFA, trifluoroacetic acid.

* Corresponding author. Tel.: +30 2310998795; fax: +30 2310998789.

E-mail address: annavafo@agro.auth.gr (A. Vafopoulou-Mastrojiannaki).
}

\section{Introduction}

In recent years the consumption of yoghurt has increased rapidly owing to the fact that this dairy product fulfils many of the current dietary needs. It is a ready-to-eat food, relatively low in fat and rich in nutritional components. Furthermore, the demand for functional foods has been boosted in recent years as a result of growing awareness among consumers of the link between diet and health (FitzGerald, Murray, \& Walsh, 2004). Yoghurt has proved to be an excellent vehicle for the production of such functional food, especially when it contains probiotic bacteria. It is also possible that the beneficial health effects of yoghurt can be increased, based on the peptides that are produced during fermentation and storage. More recently, a great interest has been focussed on peptides that can lower the blood pressure in hypertensive patients, since hypertension is a disease that is increasing at high rates, 
especially in the developed countries (FitzGerald et al., 2004).

The mechanism of action of these peptides is based on the inhibition of angiotensin-I converting enzyme (ACE, E.C. 3.4.15.1), yet the possibility cannot be excluded that their activity may include many more complex mechanisms that may promote further beneficial effects for consumer health (Fuglsang, Nilsson, \& Nyborg, 2003a; Ijäs et al., 2004; Vermeirssen, Van Camp, \& Versraete, 2004). In particular, ACE is an enzyme that has a key role in the rennin-angiotensin system, which in turn regulates the arterial blood pressure and the equilibrium of water and salt in the body. An increase in blood pressure is observed when the enzyme catalyses the hydrolysis of angiotensin I to angiotensin II, a strong vasoconstrictor agent, and the degradation of bradykinin, which has vasodilative action, to a greater extent than needed (Coates, 2003).

Many peptides with antihypertensive action have been characterised upon fermentation of milk with different microorganisms, or by the action of pure proteinases on milk proteins. Some of these peptides have been studied for their effect on spontaneously hypertensive rats, or even on small groups of human volunteers, showing positive results (FitzGerald et al., 2004; Vermeirssen et al., 2004).

Sheep milk is of great importance to Greece and has been a key raw material for the production of yoghurt with good sensory characteristics (Alichanidis \& Polychroniadou, 1996). Although the hydrolysis of sheep milk proteins in cheese has been extensively investigated, there is little information available on proteolysis in sheep milk yoghurt, especially traditional Greek yoghurt.

Hence, the aim of this study were: (a) to investigate the proteolysis during storage of traditional sheep milk Greek yoghurt and the effect thereon of a probiotic strain (Lactobacillus paracasei subsp. paracasei DC412) when used as an adjunct to the normal yoghurt culture; (b) to identify the major peptides produced during storage of the yoghurt products; (c) to measure the ACE-inhibitory activity of the products.

\section{Materials and methods}

Milk and cultures

The milk for yoghurt production was purchased from a small local yoghurt industry and was tested for $\mathrm{pH}$ (Consort C830, Belgium), titratable aciditity (AOAC, 1990), somatic cell count (Fossomatic, A/S Foss Electric, Denmark) and chemical composition (Milkoscan 104, A/S Foss Electric, Denmark). The same milk was used for the subcultures of the microorganisms.

Lactobacillus delbrueckii subsp. bulgaricus $\Upsilon 10.13$ and Streptococcus thermophillus $\Upsilon 10.7$ were isolated from goat milk yoghurt. L. paracasei subsp. paracasei DC412 was used as adjunct. All strains were identified by phenotypic criteria and SDS-PAGE of the whole cell proteins, while
L. paracase $i$ was additionally identified by rRNA-targeted oligonucleotide probe hybridization (Xanthopoulos, 2002; Xanthopoulos, Ztaliou, Gaier, Tzanetakis, \& LitopoulouTzanetaki, 1999). L. paracasei was selected for this experiment following in vitro trials regarding the probiotic potential of a series of isolates from infant faeces (Xanthopoulos, Litopoulou-Tzanetaki, \& Tzanetakis, 2000). All strains belong to the collection of the Laboratory of Food Microbiology and Hygiene, Aristotle University of Thessaloniki, Greece.

Lactobacillus strains were first subcultured in MRS broth, and Streptococcus in M17. All the strains were then subcultured twice in reconstituted skim milk $(10 \%, \mathrm{w} / \mathrm{v})$, followed by a final subculture in full fat sheep milk, previously heated at $90{ }^{\circ} \mathrm{C}$ for $30 \mathrm{~min}$, in order to be better adapted to the sheep milk environment. All the subcultures were done at $37^{\circ} \mathrm{C}$ for $18 \mathrm{~h}$.

\section{Yoghurt production}

Set type traditional Greek yoghurt was produced with full fat sheep milk heated at $85-90{ }^{\circ} \mathrm{C}$ for $30 \mathrm{~min}$ under constant stirring. The heated milk was immediately distributed in $350 \mathrm{ml}$ plastic retail containers and left to cool at $47^{\circ} \mathrm{C}$. Subsequently, a $2.5 \%(\mathrm{v} / \mathrm{v})$ inoculum was introduced into each container.

Two sets of yoghurts were produced. The first set (YC), contained L. delbrueckii subsp. bulgaricus and S. thermophilus (1:1). For the second set (PR), the same strains as for YC yoghurt were used, with addition of $L$. paracasei subsp. paracasei (2:2:1) (Table 1). The yoghurts were incubated at $42{ }^{\circ} \mathrm{C}$ for about $4 \mathrm{~h}$, until $\mathrm{pH} 4.7$ was reached. They were maintained at room temperature for $1 \mathrm{~h}$, sealed and stored at $4{ }^{\circ} \mathrm{C}$. Samples were taken at $1(1 \mathrm{~h}$ after yoghurts reached $\mathrm{pH} 4.7), 2,5,10,19$ and 26 days of storage and subjected to physicochemical analysis. The yoghurt-making trials were repeated three times.

For investigation of the proteolytic pattern of each strain used in yoghurt making, three single-strain fermented milks were produced from the same sheep milk, as follows: after heating, the milk was cooled to $37^{\circ} \mathrm{C}$, inoculated $(2 \% \mathrm{v} / \mathrm{v})$ with one of the three strains and incubated at $37^{\circ} \mathrm{C}$ for $18 \mathrm{~h}$. The fermented milks were then cooled to $4{ }^{\circ} \mathrm{C}$ and used for peptide analysis. Cultures, percentage of inocula and fermentation temperatures for all products manufactured are summarised in Table 1.

\section{Physicochemical analyses of yoghurts}

The $\mathrm{pH}$ of yoghurt samples was measured with a Consort $\mathrm{pH}$ meter (Consort C830, Belgium), acidity was titrated with $N / 9 \mathrm{NaOH}$ solution, total solids were determined by drying yoghurt samples at $102^{\circ} \mathrm{C}$ for $16 \mathrm{~h}$ (IDF, 1996) and fat content was determined using van Gulik's method (Schwarz, Hageman, Hüttig, Kellermann, \& Staege, 1950). Nitrogen content was determined by the 
Table 1

Cultures, conditions and inocula used for the production of yoghurts and fermented milks

\begin{tabular}{|c|c|c|}
\hline Strains & inoculum & Fermentation temperature $\left({ }^{\circ} \mathrm{C}\right)$ \\
\hline $\begin{array}{l}\text { Yoghurt (YC) } \\
\text { L. delbrueckii subsp. bulgaricus } \Upsilon 10.13\end{array}$ & $2.5 \% \mathrm{v} / \mathrm{v}$ & 42 \\
\hline $\begin{array}{l}\text { Yoghurt (PR) } \\
\text { L. delbrueckii subsp. bulgaricus } \Upsilon 10.13 \\
\quad \text { and L. paracasei subsp. paracasei } \mathrm{D}\end{array}$ & $2.5 \% \mathrm{v} / \mathrm{v}$ & 42 \\
\hline $\begin{array}{l}\text { Fermented milk (FM1) } \\
\text { L. delbrueckii subsp. bulgaricus } \Upsilon 10.13\end{array}$ & $2 \% \mathrm{v} / \mathrm{v}$ & 37 \\
\hline $\begin{array}{l}\text { Fermented milk (FM2) } \\
\text { S. thermophillus } \Upsilon 10.7\end{array}$ & $2 \% \mathrm{v} / \mathrm{v}$ & 37 \\
\hline $\begin{array}{l}\text { Fermented milk (FM3) } \\
\text { L. paracasei subsp. paracasei DC } 412\end{array}$ & $2 \% \mathrm{v} / \mathrm{v}$ & 37 \\
\hline
\end{tabular}

Kjeldahl method (AOAC, 1990) and the total protein was calculated as follows: Kjeldahl $N \times 6.38$.

\section{Evaluation of proteolysis during storage}

For monitoring the hydrolysis of proteins during storage of yoghurts at $4{ }^{\circ} \mathrm{C}$, water-soluble extracts (WSEs) of the samples were prepared according to the method proposed by Kuchroo and Foxfor cheese (1982). The extracts were lyophilised and kept at $-25{ }^{\circ} \mathrm{C}$ prior to further analysis. WSEs were also prepared from the fermented milks, FM1, FM2 and FM3.

The concentration of the nitrogenous compounds produced by proteolysis (reported hereafter as peptides) in the WSEs of yoghurts and related fractions was estimated using the following methods:

(a) Kjeldahl method $(N \times 6.38)($ AOAC, 1990).

(b) OPA method (Church, Swaisgood, Porter, \& Catignani, 1983). The peptide concentration was calculated from a standard curve prepared using casein peptone (Casein peptone N1, Organotechnie, France) as a reference.

(c) Direct spectrophotometric method (Scopes, 1974). The absorbances of the WSEs were measured at 280 and $205 \mathrm{~nm}$. The extinction coefficient $\left(\varepsilon_{205}^{1 \mathrm{mg} / \mathrm{ml}}\right)$ of each extract was calculated using the equation $\varepsilon_{205}^{1 \mathrm{mg} / \mathrm{ml}}=27+120 \times\left(A_{280} / A_{205}\right)$. The peptide concentration $(\mathrm{mg} / \mathrm{ml})$ was then calculated by dividing the absorbance at $205 \mathrm{~nm}$ by the extinction coefficient.

From the results obtained by each of the above methods, the degree of proteolysis was calculated using the equation $\mathrm{DH}=\mathrm{AC} / \mathrm{IC}$, where $\mathrm{DH}$ is the degree of hydrolysis, AC is the average concentration of peptides in the WSE of each set of yoghurt at each storage time, and IC is the average concentration of peptides in the WSE of the same set of yoghurt at day 1 ( $1 \mathrm{~h}$ after the completion of the fermentation).
Finally, the concentration of peptides soluble in $12 \%$ trichloroacetic acid (TCA) was determined as follows (Polychroniadou, Michaelidou, \& Paschaloudis, 1999): Ten ml of each WSE were mixed with an equal volume of $24 \%$ (w/v) TCA, the mixture was left overnight at $4{ }^{\circ} \mathrm{C}$, and the precipitate filtered through white ribbon filter paper (Schleicher and Schuell, Dassel, Germany) and used for the analysis by the Kjeldahl method (AOAC, 1990). Peptide concentration was calculated (Kjeldahl $N \times 6.38$ ).

\section{Isolation and characterization of major peptides}

Freeze-dried samples of the WSEs of yoghurts and fermented milks were dissolved in one half of their original volume with deionised water, sonicated for $5 \mathrm{~min}$ and filtered through a $0.45 \mu \mathrm{m}$ cellulose acetate filter.

Reversed-phase HPLC (RP-HPLC) was performed as described by Michaelidou, Alichanidis, Urlaub, Polychroniadou, and Zerfiridis (1998). A binary HPLC system (LKB, Bromma, Sweden) was used, fitted with a Nucleosil $\mathrm{C}_{18}$ wide pore analytical column $(5 \mu \mathrm{m}, 30 \mathrm{~nm}, 250 \times$ $4 \mathrm{~mm}$; Macherey-Nagel, Düren-Germany) and a guard column $(40 \times 4 \mathrm{~mm})$. Samples were applied using a Rheodyne injector (Rheodyne 7125, Rheodyne Inc, Cotati CA-USA), fitted with a $50 \mu$ l loop. Eluent A was $0.1 \%(\mathrm{v} / \mathrm{v})$ TFA in deionised water and eluent B was $0.09 \%(\mathrm{v} / \mathrm{v})$ TFA in a mixture of 60:40 acetonitrile (HPLC gradient, Panreac Quinica SA, Barcelona, Spain) and deionised water. Separation was conducted at room temperature $\left(\sim 20^{\circ} \mathrm{C}\right)$ at a flow rate of $0.8 \mathrm{ml} / \mathrm{min}$ with eluent $\mathrm{A}$ for $10 \mathrm{~min}$ and a linear gradient, from $0 \%$ to $80 \%$ of eluent $\mathrm{B}$, for $80 \mathrm{~min}$. The column was finally eluted with $100 \%$ eluent B for $10 \mathrm{~min}$. The absorbance of the eluate was monitored at $214 \mathrm{~nm}$, using a variable wavelength spectrophotometric detector (Fasma 525, Linear, USA), which was linked to a data acquisition and processing system (Nelson Analytical Inc., Paramus, NJ, USA).

Peptides were isolated and characterized, from the WSEs of yoghurt PR at 2, 10 and 26 days of storage and from the WSEs of the fermented milks, FM1 and FM3. 
Fractions were collected manually on a peak basis from at least 12 successive RP-HPLC runs of the selected WSEs and dried in a vacuum concentrator. Homologous peaks in RP-HPLC chromatograms of PR (at 2, 10, and 26 days), FM1 and FM3, were numbered. The peptides in each fraction were characterised by analysing the amino acid sequence using the Edman procedure.

For further separation of a group of peaks at the beginning of the chromatogram $(0-10 \mathrm{~min})$, the corresponding fraction was collected manually from 15 successive RPHPLC runs, dried under vacuum, redissolved in deionised water and fractionated again with the same system but with a flow rate of solvent $\mathrm{A}$ of $0.2 \mathrm{ml} / \mathrm{min}$. The eluate was monitored at $278 \mathrm{~nm}$.

Peptide identication

Peptides isolated by RP-HPLC (as described above) were sequenced using a model 491 automated, pulsed liquid-phase protein-peptide sequencer (Applied Biosystems, Foster City CA, USA). Amino acids liberated were detected as their phenylthiohydantoin derivatives. The partial sequence thus obtained was checked against the (known) sequence of caseins, so as to determine the most likely cleavage site.

\section{Determination of ACE-inhibitory activity}

ACE inhibitory activity was determined by the method of Cushman and Cheung (1971) as modified by Nakamura et al. (1995), with some further modifications. Each assay mixture $(250 \mu \mathrm{l})$ contained the following components at the indicated final concentrations: (a) $180 \mu \mathrm{l}$ of a hippuryl-L-histidyl-L-leucine solution $(5 \mathrm{mM})$ in sodium borate $(100 \mathrm{mM})(\mathrm{pH} 8.3)$, buffer treated with $300 \mathrm{nM} \mathrm{NaCl}$; (b) $50 \mu \mathrm{l}$ of WSE or peak material or water as a blank; (c) $20 \mu \mathrm{l}$ of a $2 \mathrm{mU}$ ACE (from rabbit lung, Sigma-Aldrich, St. Louis, MO, USA) aqueous solution. The mixture was incubated at $37^{\circ} \mathrm{C}$ for $90 \mathrm{~min}$ and the reaction was stopped with $250 \mu \mathrm{l}$ of $1 \mathrm{~N} \mathrm{HCl}$. The produced hippuric acid was extracted with $1.7 \mathrm{ml}$ of ethyl acetate, heat-evaporated at $100{ }^{\circ} \mathrm{C}$ for $15 \mathrm{~min}$, redissolved in $1 \mathrm{ml}$ of distilled water and measured spectrophotometrically at $228 \mathrm{~nm}$. The activity of each sample was tested in triplicate. The ACEinhibitory activity was expressed as percentage of inhibition of ACE activity (\%IACE) or calculated as the protein concentration needed to inhibit $50 \%$ of the original ACE activity $\left(\mathrm{IC}_{50}\right)$.

\section{Statistical analysis}

Statistical analysis was performed using SPSS 12.0 for Windows (SPSS Inc., Chicago, USA). Results were analysed by one or two-way analysis of variance. Differences between the treatment means were compared at the 5\% level of significance using LSD test.

\section{Results and discussion}

\section{Physicochemical characteristics of yoghurts}

The mean composition of sheep milk, before and after heating and of yoghurts $\mathrm{YC}$ and PR, is given in Table 2. During storage, the $\mathrm{pH}$ of both yoghurts decreased continuously, reaching a final value of ca. 3.8 (Fig. 1). Although the time effect was significant $(P<0.05)$ for both yoghurts and for all time intervals tested, the culture effect was not significant, indicating that the use of $L$. paracasei subsp. paracasei $\mathrm{DC} 412$ as an adjunct did not affect the $\mathrm{pH}$ of the product. Similar results were obtained for acidity.

Proteolysis during storage of yoghurts was estimated by three different methods: (a) the Kjeldahl method, (b) the OPA method (Church et al., 1983) and (c) the direct spectrophotometric method (Scopes, 1974). Although the absolute values obtained by the three methods for peptide concentration were different $(P<0.05)$, the degree of hydrolysis calculated were similar $(P>0.05)$; at day 26 , the degree was about 1.5 , indicating about $50 \%$ increase of the concentration of peptides from day 1 for both YC and PR. Despite this increase, the percentage of milk proteins hydrolysed remained low; on day 26 , the WSEs contained only $\sim 10 \%$ of the total $N$ of the yoghurt (data not shown). For both yoghurts and for the whole storage period, the peptides soluble in 12\% TCA composed more than $90 \%$ of the peptides of WSEs, indicating that most peptides in the WSEs had low molecular weight.

Table 2

Composition of sheep milk before and after heating at $85-90{ }^{\circ} \mathrm{C}$ for $30 \mathrm{~min}$ and of yoghurt after fermentation at $42{ }^{\circ} \mathrm{C}^{\mathrm{a}}$

\begin{tabular}{lccr}
\hline Chemical characteristics & \multicolumn{1}{l}{ Milk } & Yoghurt (YC and PR) \\
\cline { 2 - 3 } & Before thermal process & After thermal process & $6.6 \pm 0.1$ \\
\hline Fat (\%) & $5.93 \pm 0.15$ & $6.47 \pm 0.07$ & $6.34 \pm 0.05$ \\
Protein (\%) ${ }^{\mathrm{b}}$ & $5.8 \pm 0.09$ & $6.31 \pm 0.12$ & $18.05 \pm 0.03$ \\
Total solids (\%) & $16.7 \pm 0.23$ & $18.22 \pm 0.17$ & - \\
Lactose (\%) & $4.28 \pm 0.13$ & $4.72 \pm 0.05$ & $4.45 \pm 0.03$ \\
pH & $6.6 \pm 0.03$ & $6.55 \pm 0.02$ & $1.04 \pm 0.01$ \\
Lactic acid (\%) & $0.19 \pm 0.005$ & $0.22 \pm 0.005$ & - \\
Somatic cells/ml & 350,000 & - & \\
\hline
\end{tabular}

\footnotetext{
${ }^{a}$ Analyses were performed in triplicate. Values are means \pm SD.

${ }^{\mathrm{b}}$ Protein $=$ total nitrogen $\times 6.38$.
} 


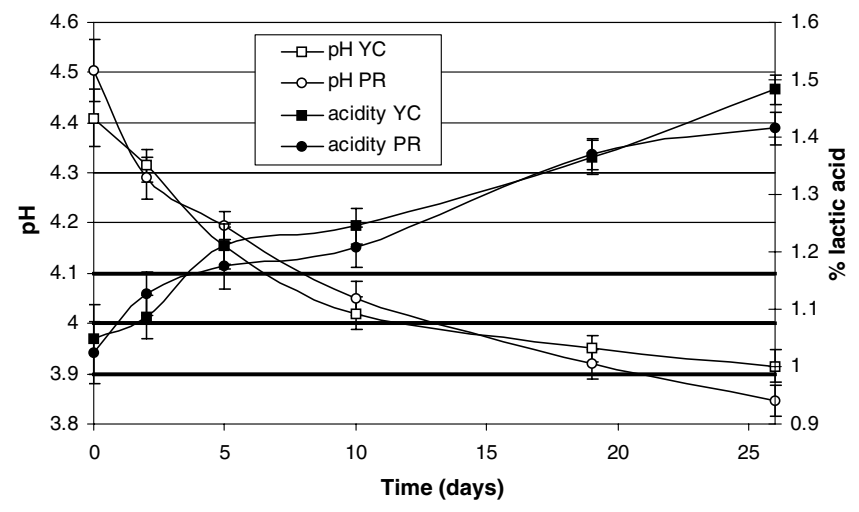

Fig. 1. $\mathrm{pH}$ and acidity of traditional Greek sheep milk yoghurts during storage at $4{ }^{\circ} \mathrm{C}$. Yoghurt YC was inoculated with $L$. delbrueckii subsp. bulgaricus $\Upsilon 10.13$ and $S$. thermophillus $\Upsilon 10.7$. Yoghurt PR was inoculated with the previous two microorganisms and $L$. paracasei subsp. paracasei DC412 as an adjunct. Vertical bars represent standard errors $(n=6)$.

\section{Isolation and identication of major peptides}

The WSEs of the yoghurts (YC and PR) at different ages were analysed by RP-HPLC. The peptide profiles obtained were similar and only some quantitative differences were observed, concerning the area of some peaks (data not shown). In Fig. 2, representative chromatograms of 2, 10 and 26-day-old samples of PR are shown, together with chromatograms of the fermented milks, FM1, FM2 and FM3. Analysis of the last three chromatograms reveals that there is a high degree of similarity between the peptide profiles of $L$. delbrueckii subsp. bulgaricus (FM1) and L. paracasei subsp. paracasei (FM3) as far as the number and retention times of the peaks are concerned. This observation, combined with the low proteolytic capacity of $S$. thermophilus, may explain, at least partially, the minor differences in peptide profiles of YC and PR yoghurts, as mentioned above.

The chromatograms of WSEs of yoghurt PR (Fig. 2) show that most of the peaks were formed by the second day of storage. During storage the peaks increased in height but no significant changes in the chromatographic profile occurred.

Twelve peptides were identified, most of which originated from $\beta$-casein (Table 3). None of the identified peptides was a phosphopeptide although other authors identified phosphopeptides in other fermented milks (Chianese et al., 2003; Courtin \& Rul, 2004). On the other hand, the absence of peptides originating from whey proteins in yoghurt PR is a phenomenon that has also been reported for other fermented milks (Bertrand-Harb, Ivanova, Dalgalarrondo, \& Heartlle, 2003; Chianese et al., 2003; Quirós, Hernández-Ledesma, Ramos, Amigo, \& Recio, 2005).

In particular, eight peptides originated from $\beta$-casein. Almost all of them had the same N-terminal sequence (peaks $3,5,11,12,14,15$ ) as that of peptides released by the action of lactococcal proteinases (Gobbetti, Ferranti,
Smacchi, Goffredi, \& Addeo, 2000; Juillard et al., 1995; Kunji, Mierau, Hagting, Poolman, \& Konings, 1996).

The peptide identified in peaks 6,8 and $13\left(\alpha_{\mathrm{s} 1}-\mathrm{CN}\right.$ f1-8) was the only peptide derived from $\alpha_{\mathrm{s} 1}$-casein, and it was possibly produced by the action of $L$. bulgaricus on sheep $\alpha_{\mathrm{s} 1}$-casein.

Only one peptide, $\alpha_{\mathrm{s} 2}-\mathrm{CN}$ f79-82, was identified from $\alpha_{\mathrm{s} 2}$-casein. It was produced by $L$. bulgaricus and was coeluted in peak 6 , together with peptide $\alpha_{s 1}-\mathrm{CN}$ f1-8. Although peptide $\alpha_{\mathrm{s} 1}-\mathrm{CN}$ f1-8 was also identified in other peaks of the yoghurt PR, peptide $\alpha_{\mathrm{s} 2}-\mathrm{CN}$ f79-82 was not identified in yoghurt PR, possibly because it was further hydrolysed by the other two microorganisms present in the mixed bacterial culture.

Peptide $\kappa-\mathrm{CN}$ f53-60 was the only identified peptide derived from $\kappa$-casein and it was found only in yoghurt PR. From the evolution chromatograms (Fig. 2), it can be seen that peptide $\kappa-\mathrm{CN}$ f53-60 was probably produced during the first days of storage and its concentration rose gradually up to day 26 .

\section{ACE-inhibitory activity and relative peptides}

The possible presence of ACE-inhibitory peptides in yoghurts YC and PR was first investigated using WSEs as testing material. The ACE-inhibitory activity of the WSEs throughout storage (\%IACE) is presented in Fig. 3. As can be seen, the ACE-inhibitory activity increased during storage and was positively correlated with the peptide concentration in WSEs. Similar results were found in a report of 26 different strains of lactic acid bacteria, where a high correlation between the concentration of peptides and the percentage of inhibition of ACE was shown (Fuglsang, Rattray, Nilsson, \& Nyborg, 2003b).

No significant $(P>0.05)$ differences were found between the two yoghurts in respect to ACE-inhibitory activity, a fact that is supported by similarities in the chromatograms of their WSEs. The concentration of peptides needed to inhibit $50 \%$ of ACE $\left(\mathrm{IC}_{50}\right)$ ranged from 1.49 to $1.62 \mathrm{mg} /$ $\mathrm{ml}$. The degree of inhibition of ACE of the WSEs and the calculated $\mathrm{IC}_{50}$ values are in accordance with the results reported by other researchers (Fuglsang et al., 2003b; Hernández-Ledesma, Amigo, Ramos, \& Recio, 2004; Hernández-Ledesma, Martin-Alvarez, \& Pueyo, 2003). Leclerc, Gauthier, Bachelard, Santure, and Roy (2002) found similar $\mathrm{IC}_{50}$ values, $1.15-1.68 \mathrm{mg} / \mathrm{ml}$, from the action of Lactobacillus helveticus on milk proteins.

To identify the peptides responsible for the inhibition of ACE, the WSE of the 26-day-old yoghurt PR was subjected to RP-HPLC analysis. Nine different fractions were collected and evaluated for their ACE-inhibitory activity (Fig. 4). The material included in fraction 1, which had the highest ACE-inhibition activity, was collected from 12 successive runs, lyophilised, redissolved and resubjected to chromatography. Two fractions were obtained therefrom and were further tested for ACE-inhibitory activity. Fraction 1.1 showed the highest inhibitory activity on 

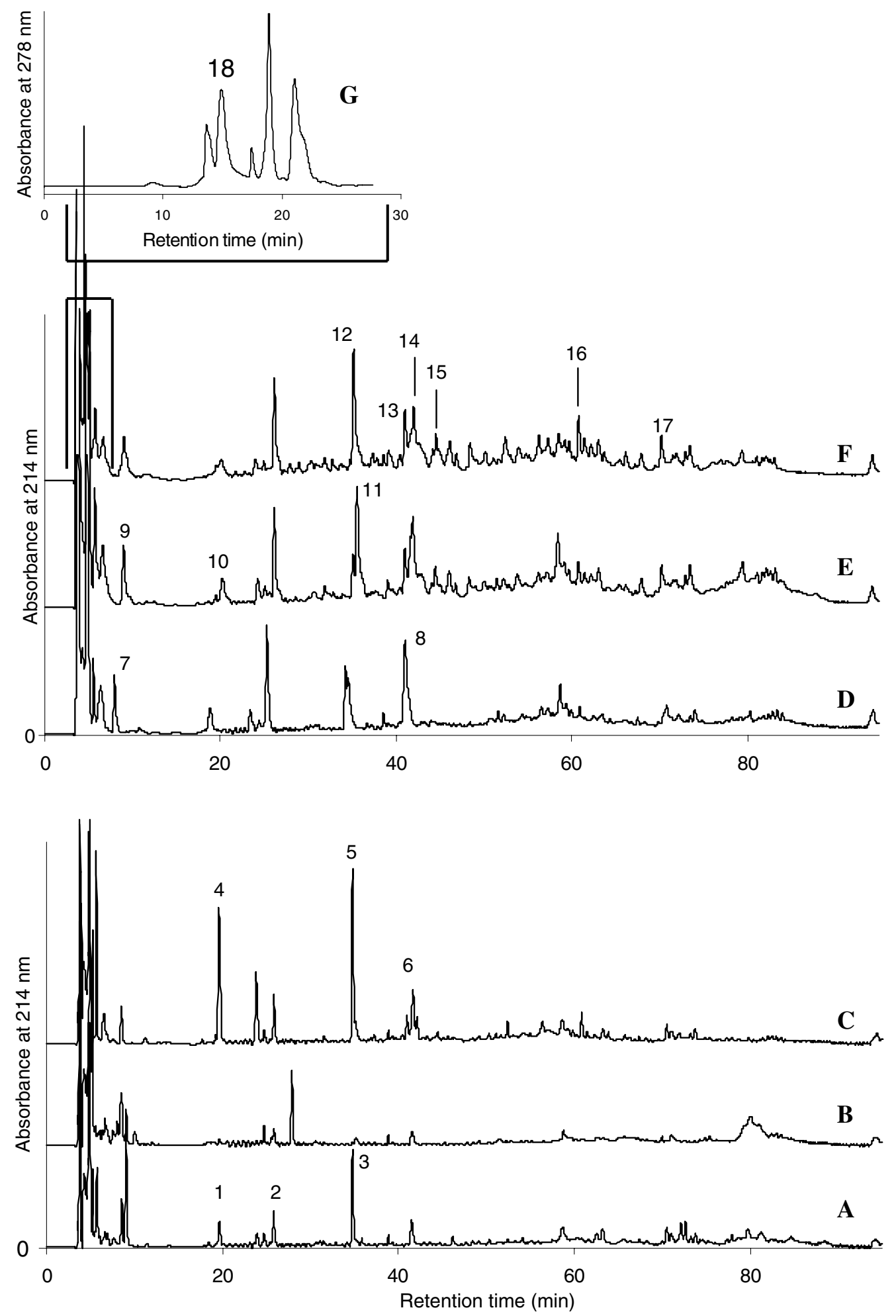

Fig. 2. RP-HPLC profiles of the water-soluble extracts obtained from single-culture fermented milks (A: FM3, L. paracasei subsp. paracasei DC412; B: FM2, S. thermophilus Ү10.7; C: FM1, L. delbrueckii subsp. bulgaricus $\Upsilon 10.13$ ) and from yoghurt PR at 2 (D), 10 (E) and 26 (F) days of storage. Chromatogram $\mathrm{G}$ is the profile of the indicated part in chromatogram $\mathrm{F}$ under different conditions (see Section 2). Material corresponding to the numbered peaks was collected and identified.

ACE and was further purified using different chromatographic conditions (see Section 2). The material of five peaks (Fig. 4A-E) was collected and subsequently tested for ACE-inhibitory activity.
The peptide contained in peak B (previously numbered as peak 18), showing the highest ACE-inhibitory activity $\left(\mathrm{IC}_{50}: 0.37 \mathrm{mg} / \mathrm{ml}\right.$ ), was sequenced. It corresponded to YPVEPFTE, originating from $\beta$-casein $(\beta-\mathrm{CN}$ f114-121). 
Table 3

Peptides identified in the water-soluble extracts of yoghurt PR and the single-strain fermented milks, FM1 (L. delbrueckii subsp. bulgaricus $\Upsilon 10.13$ ) and FM3 (L. paracasei subsp. paracasei DC412)

\begin{tabular}{|c|c|c|c|}
\hline $\begin{array}{l}\text { RP-HPLC peak } \\
\text { number }\end{array}$ & $\begin{array}{l}\text { Sequence (one-letter } \\
\text { symbol) }\end{array}$ & Casein fragment & $\begin{array}{l}\text { Corresponding yoghurt or } \\
\text { fermented milk }\end{array}$ \\
\hline $1,4,10$ & $\mathrm{Y}$ & & PR, FM1, FM3 \\
\hline 2 & KAVPQ & $\beta-C N$ f176- $180^{b}$ & FM3 \\
\hline 3 & GVPKVK & $\beta-C N$ f $94-99$ & FM3 \\
\hline $5,11,12$ & GVPKVKE & $\beta-\mathrm{CN}$ f94-100 & PR, FM1 \\
\hline 6 & $\begin{array}{l}\text { RPKHPIKH } \\
\text { YQKA }\end{array}$ & $\begin{array}{l}\alpha_{\mathrm{s} 1}-\mathrm{CN} \mathrm{f1-8} \\
\alpha_{\mathrm{s} 2-\mathrm{CN} \mathrm{f79-82}}\end{array}$ & FM1 \\
\hline 7,9 & $(\mathrm{~T} / \mathrm{H} / \mathrm{Y} / \mathrm{A}) \mathrm{P}$ & $\begin{array}{l}45 \text { possible combinations from } \alpha_{\mathrm{s} 1}-\mathrm{CN}, \\
\alpha_{\mathrm{s} 2}-\mathrm{CN}, \beta-\mathrm{CN}, \kappa-\mathrm{CN} \text { and } \beta \text {-lactoglobulin }\end{array}$ & PR \\
\hline 8,13 & RPKHPIKH & $\alpha_{s 1}-C N$ f1-8 & PR \\
\hline 14 & $\begin{array}{l}\text { SQPK } \\
\text { YQEP }\end{array}$ & $\begin{array}{l}\beta-C N \text { f } 166-169 \\
\beta-C N \text { f } 191-194\end{array}$ & PR \\
\hline 15 & DKIHPFAQ & $\beta-C N$ f $47-54$ & PR \\
\hline 16 & NQFLPYPY & $\kappa-C N$ f53-60 & PR \\
\hline 17 & TQTPVVVP & $\beta-C N$ f78-85 & PR \\
\hline 18 & YPVEPFTE & $\beta-C N$ f114-121 & PR \\
\hline
\end{tabular}

${ }^{a}$ The peak numbers refer to those shown in Fig. 2.

${ }^{\mathrm{b}} \mathrm{CN}$ : casein.

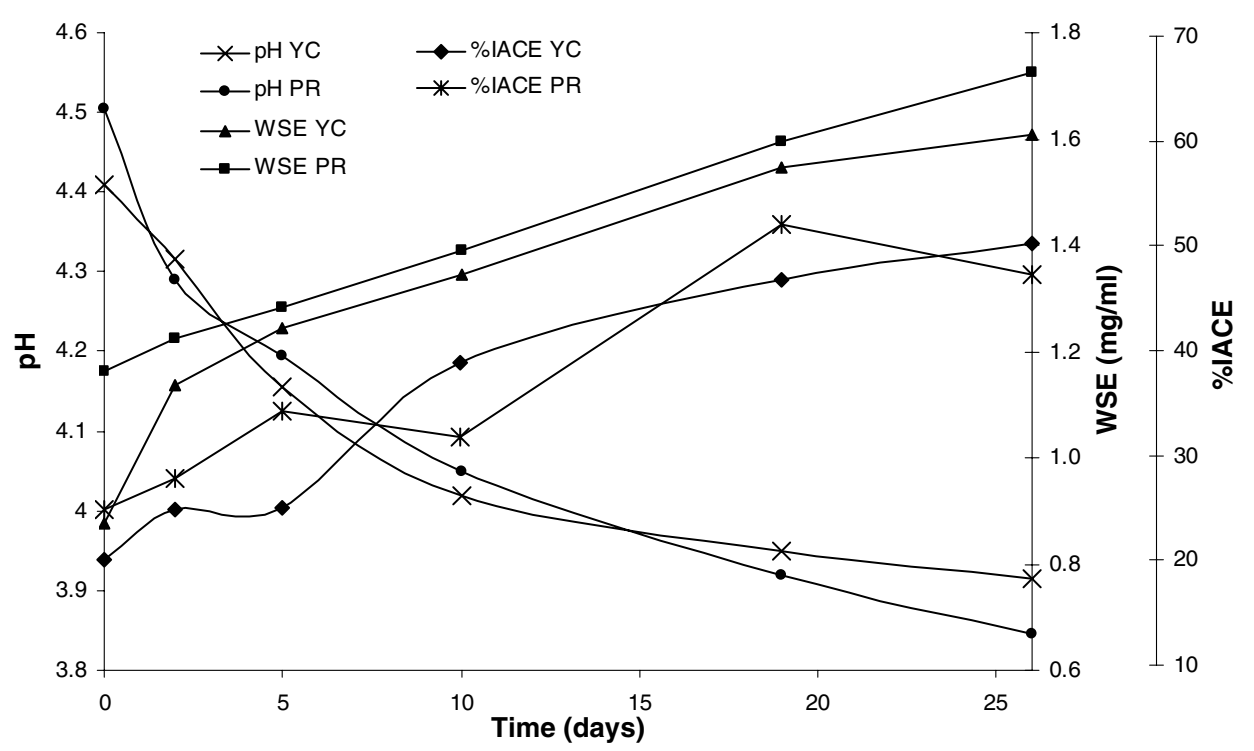

Fig. 3. $\mathrm{pH}$, peptide concentration of the water-soluble extracts (WSE, $\mathrm{mg} / \mathrm{ml}$ ) and percentage of inhibition of ACE (\%IACE) during storage of yoghurts YC and PR (means of six replications).

Lebrun et al. (1995) isolated the same peptide by hydrolysis of $\gamma$-casein with trypsin; the peptide exhibited bradykininpotentiating effects on isolated guinea-pig ileum and on rat arterial blood pressure. Further research on this peptide has shown that it is not only related to the inhibition of ACE, but also possibly related to the inhibition of other enzymes participating in the degradation of bradykinin (Perpetuo, Juliano, \& Lebrun, 2003). Injection of this peptide into rats also presented an opiate-like activity by showing a 2-fold increase of latency time to pain in the hot-plate assay (Perpetuo et al., 2003).

According to literature data (Maeno, Yamamoto, \& Takano, 1996; Yamamoto, Maeno, \& Takano, 1999), there are existing reports on incidences of important decrease of arterial blood pressure upon ingestion of peptides that had shown low ACE-inhibitory activity in vitro. Furthermore, processing of casein hydrolysates, derived from starter cultures, with pepsin and trypsin, greatly increased the percentage of inhibition of ACE of these hydrolysates (Pihlanto-Leppala, Rokka, \& Korhonen, 1998). Therefore, it seems likely that the combined action of different proteolytic agents can lead to a greater inhibition of ACE compared to the original product. Hence, we could speculate that apart from peptide $\beta-\mathrm{CN}$ f114-121, five other sequenced peptides could also act as ACE-inhibitors, if further hydrolysed by the enzymes of the intestinal tract (Table 4). For example, Minervini et al. (2003), found that peptide $\alpha_{\mathrm{s} 1}-\mathrm{CN}$ f1-4 has a high antihypertensive effect 


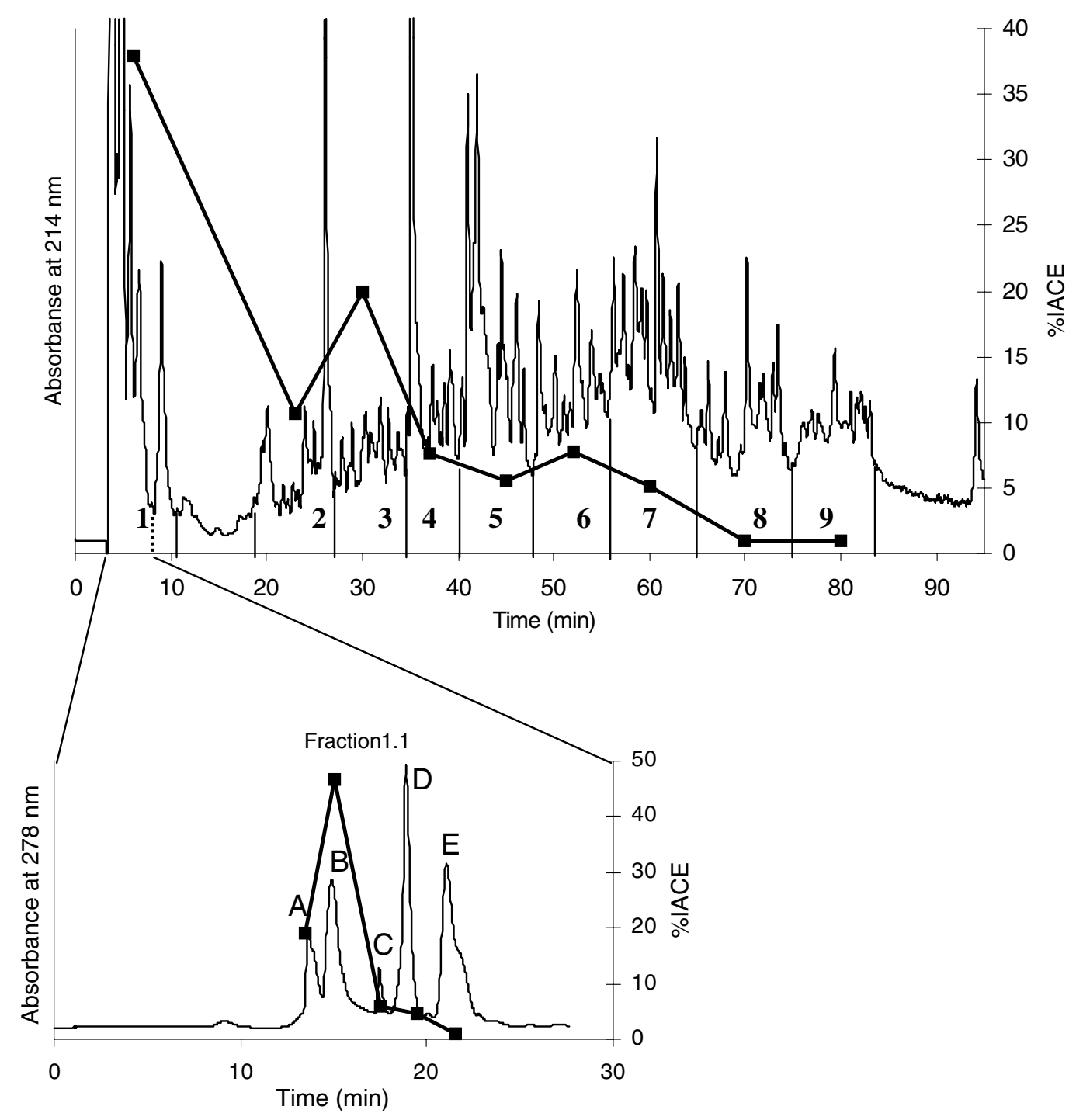

Fig. 4. RP-HPLC chromatogram of the water-soluble extracts of yoghurt PR after 26 days of storage: fractions collected are numbered and the corresponding percentages of ACE-inhibitory activity (\%IACE) are presented. The lower chromatogram is part of fraction 1 (dotted line, fraction 1.1) under different chromatographic conditions (absorbance at $278 \mathrm{~nm}$; flow rate $0.2 \mathrm{ml} / \mathrm{min}$ ). Each peak of this chromatogram was collected separately and the ACE-inhibitory activity tested.

Table 4

Antihypertensive peptides sharing structure homology with the sequenced peptides of this study

\begin{tabular}{|c|c|c|c|c|}
\hline $\begin{array}{l}\text { RP-HPLC Peak } \\
\text { number }\end{array}$ & $\begin{array}{l}\text { Sequence (one-letter } \\
\text { symbol) }\end{array}$ & $\begin{array}{l}\text { Sequence } \\
\text { reported }\end{array}$ & Activity & References \\
\hline 15 & DKIHPFAQ & DKIHPF & Antihypertensive $\left(\mathrm{IC}_{50} 257 \mu \mathrm{M}\right)$ & Gobbetti et al. (2000) \\
\hline 15 & DKIHPFAQ & DKIHP & $\begin{array}{l}\text { Antihypertensive }\left(\mathrm{IC}_{50} 234 \mu \mathrm{g} / \mathrm{ml}, \mathrm{IC}_{50}\right. \\
113 \mu \mathrm{M} \text { or } 578 \mu \mathrm{M})\end{array}$ & $\begin{array}{l}\text { Quirós et al. (2005), Gomez-Ruiz } \\
\text { et al. (2004) }\end{array}$ \\
\hline 17 & TQTPVVVP & NIPPLTQTPV & Antihypertensive $\left(\mathrm{IC}_{50} 173 \mu \mathrm{M}\right)$ & Gobbetti et al. (2000) \\
\hline 2 & KAVPQ & SKVLPVPQ & Antihypertensive $\left(\mathrm{IC}_{50} 39 \mu \mathrm{M}\right)$ & Yamamoto et al. (1994) \\
\hline $6,8,13$ & RPKHPIKH & RPKHPI & Antihypertensive ( $\left.\mathrm{IC}_{50} 40.3 \mu \mathrm{M}\right)$ & Minervini et al. (2003) \\
\hline
\end{tabular}

Residues in bold letters indicate sequence homology of fractions.

in vitro $\left(\mathrm{IC}_{50}: 30.1 \mu \mathrm{g} / \mathrm{ml}\right)$. This peptide is part of the sequence of the, peptide $\alpha_{\mathrm{s} 1}$-CN f1-8, which was identified in peaks 6 of FM1 and 8 and 13 of yoghurt PR. Although the relationship between structure and mechanism of action of the ACE-inhibitors is not yet clear, it seems likely that the three C-terminal amino acids play an important role. They are preferably hydrophobic amino acids (aromatic or with branched side chains) or the iminoacid 
proline (Meisel, 1998). The peptides presented in Table 4 as precursors of ACE-inhibitors, were selected, based on these estimations.

\section{Conclusion}

In this study the proteolytic activity of $L$. delbrueckii subsp. bulgaricus $\Upsilon 10.13, S$. thermophilus $\Upsilon 10.7$ and $L$. paracasei subsp. paracasei DC412, in mixed or plain cultures, was examined during their growth in sheep milk. L. delbrueckii subsp. bulgaricus $\Upsilon 10.13$ was the most proteolytic, followed closely by $L$. paracasei subsp. paracasei DC412, with similar proteolytic profiles. Examination of the probiotic yoghurt for the presence of antihypertensive peptides revealed the presence of a peptide, i.e. $\beta-\mathrm{CN}$ f114-121, reported as having both antihypertensive and opiate-like activity. Based on our results, it is suggested that this traditional product may possess multifunctional health effects, due to the presence of probiotics and bioactive peptides. Nevertheless, further investigation is needed in order to demonstrate these health benefits via in vivo trials and clinical studies.

\section{Acknowledgements}

The authors thank Prof. N. Tzanetakis and the Laboratory of Food Microbiology and Hygiene, Aristotle University of Thessaloniki, Greece, for supplying the strains of microorganisms used in this study. In addition, we are grateful to E. Haritonidou and N. Paschaloudis for their technical assistance. The research of Chr. Papadimitriou was funded by the Greek State Scholarships Foundation.

\section{References}

Alichanidis, E., \& Polychroniadou, A. (1996). Special features of dairy products from ewe and goat milk from the physicochemical and organoleptic point of view. Production and utilization of ewe and goat milk (pp. 21-43). Athens, Greece: International Dairy Federation (IDF special issue).

AOAC (1990). In K. Helrich (Ed.), Official methods of analysis (15th ed.). Arlington, VA: Association of Official Analytical Chemists.

Bertrand-Harb, C., Ivanova, I. V., Dalgalarrondo, M., \& Heartlle, T. (2003). Evolution of $\beta$-lactoglobulin and $\alpha$-lactalbumin content during yoghurt fermentation. International Dairy Journal, 13, 39-45.

Chianese, L., Caira, S., Pizzolongo, F., Melck, D., Ferranti, P., Merusi, P., et al. (2003). Production of a probiotic yogurt with increased levels of bioactive peptides. In Fermented milk (pp. 290-301). Brussels: International Dairy Federation (IDF special issue).

Church, F. C., Swaisgood, H. E., Porter, D. H., \& Catignani, L. (1983). Spectrophotometric assay using $o$-phthaldialdehyde for determination of proteolysis in milk and isolated milk proteins. Journal of Dairy Science, 66, 1219-1227.

Coates, D. (2003). Molecules in focus: The Angiotensin converting enzyme (ACE). International Journal of Biochemistry and Cell Biology, 35, 769-773.

Courtin, P., \& Rul, F. (2004). Interactions between microorganisms in a simple ecosystem: yogurt bacteria as a study model. Lait, 84, 125-134.

Cushman, D. W., \& Cheung, H. S. (1971). Spectrophotometric assay and properties of the angiotensin-converting enzyme of rabbit lung. Biochemical Pharmacology, 20, 1637-1648.
FitzGerald, R. J., Murray, B. A., \& Walsh, D. J. (2004). Hypotensive peptides from milk proteins. Journal of Nutrition, 134, 980S-988S.

Fuglsang, A., Nilsson, D., \& Nyborg, N. C. B. (2003a). Characterization of new milk-derived inhibitors of angiotensin converting enzyme in vitro and in vivo. Journal of Enzyme Inhibition and Medicinal Chemistry, 18, 407-412.

Fuglsang, A., Rattray, F. P., Nilsson, D., \& Nyborg, N. C. B. (2003b). Lactic acid bacteria: Inhibition of angiotensin converting enzyme in vitro and in vivo. Antonie van Leeuwenhoek, 83, 27-34.

Gobbetti, M., Ferranti, P., Smacchi, E., Goffredi, F., \& Addeo, F. (2000). Production of angiotensin-I-converting-enzyme-inhibitory peptides in fermented milks started by Lactobacillus delbrueckii subsp. bulgaricus SS1 and Lactococcus lactis subsp. cremoris FT4. Applied and Environmental Microbiology, 66, 3898-3904.

Gomez-Ruiz, J. A., Recio, I., \& Belloque, J. (2004). ACE-Inhibitory activity and structural properties of peptide Asp-Lys-Ile-His-Pro [ $\beta$ $\mathrm{CN}$ f(47-51)]. Study of the peptide forms synthesized by different methods. Journal of Agricultural and Food Chemistry, 52, 6315-6319.

Hernández-Ledesma, B., Amigo, L., Ramos, M., \& Recio, I. (2004). Angiotensin-converting enzyme inhibitory activity in commercial fermented products. Formation of peptides under simulated gastrointestinal digestion. Journal of Agricultural and Food Chemistry, 52, 1504-1510.

Hernández-Ledesma, B., Martin-Alvarez, P. J., \& Pueyo, E. (2003). Assessment of the spectrophotometric method for determination of angiotensin-converting-enzyme activity: Influence of the inhibition type. Journal of Agricultural and Food Chemistry, 51, 4175-4179.

IDF, International Dairy Federation (1996). Dry matter determination, Reference method, IDF Standard 151. Brussels: International Dairy Federation.

Ijäs, H., Collin, M., Finckenberg, P., Pihlanto-Leppälä, A., Korhonen, H., Korpela, R., et al. (2004). Antihypertensive opioid-like milk peptide $\alpha$ lactorphin: lack of effect on behavioural tests in mice. International Dairy Journal, 14, 201-205.

Juillard, V., Laan, H., Kunji, E. R. S., Jeronimus-Stratingh, C. M., Bruins, A. P., \& Konings, W. N. (1995). The extracellular PI type proteinase of Lactococcus hydrolyzes $\beta$-casein into more than one hundred different oligopeptides. Journal of Bacteriology, 177, 3472-3478.

Kuchroo, C. N., \& Fox, P. F. (1982). Soluble nitrogen in Cheddar cheese: comparison of extraction procedures. Milchwissenschaft, 37, 331-335.

Kunji, E. R. S., Mierau, I., Hagting, A., Poolman, B., \& Konings, W. N. (1996). The proteolytic systems of lactic acid bacteria. Antonie van Leeuwenhoek, 70, 187-221.

Lebrun, I., Lebrun, F. L., Henriques, O. B., Carmona, A. K., Juliano, L., \& Camargo, A. C. (1995). Isolation and characterization of a new bradykinin potentiating octapeptide from gamma-casein. Canadian Journal of Physiology and Pharmacology, 73, 85-91.

Leclerc, P.-L., Gauthier, S. F., Bachelard, H., Santure, M., \& Roy, D. (2002). Antihypertensive activity of casein-enriched milk fermented by Lactobacillus helveticus. International Dairy Journal, 12, 995-1004.

Maeno, M., Yamamoto, N., \& Takano, T. (1996). Identification of an antihypertensive peptide from casein hydrolysates produced by a proteinase from Lactobacillus helveticus CP790. Journal of Dairy Science, 79, 1316-1321.

Meisel, H. (1998). Overview on milk proteins-derived peptides. International Dairy Journal, 8, 363-373.

Michaelidou, A., Alichanidis, E., Urlaub, H., Polychroniadou, A., \& Zerfiridis, G. K. (1998). Isolation and identification of some major water-soluble peptides in Feta cheese. Journal of Dairy Science, 81, 3109-3116.

Minervini, F., Algaron, F., Rizzello, C. G., Fox, P. F., Monnet, V., \& Gobbetti, M. (2003). Angiotensin I-converting-enzyme-inhibitory and antibacterial peptides from Lactobacillus helveticus PR4 proteinasehydrolysed caseins of milk from six species. Applied and Environmental Microbiology, 69, 5297-5305.

Nakamura, Y., Yamamoto, N., Sakai, K., Okubo, A., Yamazaki, S., \& Takano, T. (1995). Purification and characterization of angiotensin 
I-converting enzyme inhibitors from sour milk. Journal of Dairy Science, 78, 777-783.

Perpetuo, E. A., Juliano, L., \& Lebrun, I. (2003). Biochemical and pharmacological aspects of two bradykinin-potentiating peptides obtained from tryptic hydrolysis of casein. Journal of Protein Chemistry, 22, 601-606.

Pihlanto-Leppala, A., Rokka, T., \& Korhonen, H. (1998). Angiotensin Iconverting enzyme inhibitory peptides derived from bovine milk proteins. International Dairy Journal, 8, 325-331.

Polychroniadou, A., Michaelidou, A., \& Paschaloudis, N. (1999). Effect of time, temperature and extraction method on the trichloroacetic acidsoluble nitrogen in cheese. International Dairy Journal, 9, 559-568.

Quirós, A., Hernández-Ledesma, B., Ramos, M., Amigo, L., \& Recio, I. (2005). Angiotensin-converting enzyme inhibitory activity of peptides derived from caprine Kefir. Journal of Dairy Science, 88, 3480-3487.

Schwarz, G., Hageman, B., Hüttig, C., Kellermann, R., \& Staege, W. (1950). Untersuchung von Milch Milcherzeugnissen und Molkereihilfsstoffen. Methodenbuch Band VI (2nd ed.). Radebeul, Germany: NeumannVerlag.

Scopes, R. K. (1974). Measurement of protein by spectrophotometry at $205 \mathrm{~nm}$. Analytical Biochemistry, 59, 277-282.
Vermeirssen, V., Van Camp, J., \& Versraete, W. (2004). Bioavailability of angiotensin I converting enzyme inhibitory peptides. British Journal of Nutrition, 92, 357-366.

Xanthopoulos, V. (2002). Selection of wild and from infant feces derived strains of lactic acid bacteria for the production of a fermented goat milk product with potential probiotic action. $\mathrm{PhD}$ thesis (in Greek), Aristotles University of Thessaloniki, Thessaloniki, Greece.

Xanthopoulos, V., Litopoulou-Tzanetaki, E., \& Tzanetakis, N. (2000). Characterization of Lactobacillus isolates from infant faeces as dietary adjuncts. Food Microbiology, 17, 205-215.

Xanthopoulos, V., Ztaliou, I., Gaier, W., Tzanetakis, N., \& LitopoulouTzanetaki, E. (1999). Differentiation of lactic acid bacteria isolates from infant feces by SDS_PAGE and r-RNA-targeted oligonucleotide probes. Journal of Applied Microbiology, 87, 743-749.

Yamamoto, N., Akino, A., \& Takano, T. (1994). Antihypertensive effect of the peptides derived from casein by an extracellular proteinase from Lactobacillus helveticus CP790. Journal of Dairy Science, 77, 917-922.

Yamamoto, N., Maeno, M., \& Takano, T. (1999). Purification and characterization of an antihypertensive peptide from a yogurt-like product fermented by Lactobacillus helveticus CPN4. Journal of Dairy Science, 82, 1388-1393. 